\title{
HUBUNGAN JUMLAH LOGAM KROMIUM (Cr) PADA AIR IRIGASI, TANAH SAWAH DAN GABAH DI KAWASAN INDUSTRI DI KECAMATAN KEBAKKRAMAT KABUPATEN KARANGANYAR
}

\author{
Sari Mukti Rohmawati ${ }^{1 *)}$, Sutarno $^{2)}$ dan Mujiyo ${ }^{2)}$ \\ ${ }^{1)}$ Program Studi Agroteknologi, Fakultas Pertanian, Universitas Sebelas Maret \\ ${ }^{2)}$ Program Studi Ilmu Tanah, Fakultas Pertanian, Universitas Sebelas Maret \\ *Corresponding author: sarimuktirohmawati@student.uns.ac.id
}

\begin{abstract}
Subdistrict Kebakkaramat was the region with the second largest number after sub-district industrial Jaten. Kebakkramat industry in the district is dominated by the textile industry wastewater produced allegedly pollute streams and rivers used by farmers as irrigation water. Waste that pollutes streams and rivers is thought to contain Cr. The use of irrigation water suspected to contain Cr feared to be absorbed by plants and then accumulates in the grain. The purpose of this study was to determine the relationship between the content of $\mathrm{Cr}$ in the irrigation water, soil, and paddy rice fields. This research uses descriptive exploratory methods implemented through field surveys and followed by laboratory analysis. Variable observations from this study include $\mathrm{Cr}$. $\mathrm{Cr}$ at all observation points, except the control, does not correspond to the irrigation water quality standard, that exceeds a predetermined limit is $0.01 \mathrm{ppm}$.
\end{abstract}

Keywords: Cr; Industrial; Paddy soil; Rice; Waste

Cite this as: Rohmawati, S., Sutarno, S., \& Mujiyo, M. 2017. Hubungan Jumlah Logam Kromium (Cr) pada Air Irigasi, Tanah Sawah dan Gabah di Kawasan Industri di Kecamatan Kebakkramat Kabupaten Karanganyar. Caraka Tani: Journal of Sustainable Agriculture. 32(1), 14-17. doi: http://dx.doi.org/10.20961/carakatani.v32i1.15898

\section{PENDAHULUAN}

Kecamatan Kebakkramat merupakan wilayah penghasil produksi padi terbesar di Kabupaten Karanganyar dan juga wilayah dengan jumlah industri yang paling banyak setelah Kecamatan Jaten. Industri di Kecamatan Kebakkramat didominasi oleh industri tekstil yang diduga membuang limbah cair ke sungai dan saluran air irigasi. Sawah di Kecamatan Kebakkramat merupakan sawah dengan irigasi teknis. Pada musim kemarau seperti saat ini petani mengairi sawahnya langsung dari air sungai dan saluran air menggunakan pompa diesel. Suganda et al. (2002) menjelaskan air sungai yang teraliri limbah industri dapat menurunkan kualitas dan produktivitas lahan sawah dan kualitas hasil tanaman.

Pengaruh air irigasi pada tanah yang dialirinya dapat bersifat netral, suplementer, memperkaya maupun memiskinkan. Air irigasi bersifat netral yaitu didapatkan pada tanah-tanah yang menerima pengairan dari air yang berasal dan melalui daerah aliran yang memiliki jenis tanah yang sama dengan tanah yang dialiri. Sifat suplementer yaitu pada tanah yang telah kehilangan unsur-unsur hara akibat pencucian dan mendapatkan unsurunsur hara lain dari air irigasi. Air irigasi bersifat memperkaya tanah apabila kandungan unsur hara akibat dari pengairan lebih besar jumlahnya daripada unsur hara yang hilang karena panen, drainase atau pengairan. Pencucian unsur hara dari permukaan kompleks adsorpsi dan larutan tanah oleh air irigasi bersifat memiskinkan tanah (Suyana dan Widijanto, 2002).

Potensi logam berat yang terdapat dalam air irigasi ini diduga adalah logam Cr karena 52\% industri di Kecamatan Kebakkramat adalah industri tekstil yang menghasilkan limbah salah satunya adalah logam berat Cr. Penelitian ini dilakukan untuk mengetahui hubungan logam $\mathrm{Cr}$ dalam air irigasi, tanah sawah dan gabah di kawasan industri Kebakkramat. 


\section{METODE PENELITIAN}

Penelitian ini merupakan penelitian deskriptif kuantitatif yang dilaksanakan melalui survei lapang. Untuk mengetahui logam $\mathrm{Cr}$ pada air irigasi, tanah sawah dan gabah di kawasan industri Kebakkramat dilakukan pengambilan sampel air, tanah sawah dan gabah yang diduga tercemar limbah industri. Penelitian ini dilakukan selama satu periode musim tanam padi dan pengambilan sampel air dilakukan sebanyak 2 kali, sedangkan tanah sawah dan gabah diambil 1 kali.

Penentuan titik sampel dilakukan secara sengaja (purposive sampling). Pemilihan titik ditentukan dengan memilih 8 (delapan) pasangan titik sampel yang berada di sekitar industri, dan sebagai kontrol diambil 1 (satu) pasangan titik sampel yang berada di luar kawasan industri. Penentuan titik sampel dilakukan melalui proses pemetaan menggunakan aplikasi Arcview GIS 3.3 di Laboratorium Pedologi dan Survei Tanah seperti tersaji pada Gambar 1.

Analisis logam berat $\mathrm{Cr}$ dilakukan secara spektofotometri serapan atom nyala. Ekstraksi sampel dilakukan dengan cara $5 \mathrm{ml}$ asam nitrat ditambahkan ke dalam sampel air yang dipipet $200 \mathrm{ml}$ dalam gelas piala kemudian dipanaskan hingga 15 sampai $20 \mathrm{ml}$ dan diencerkan dalam labu ukur $50 \mathrm{ml}$ hingga tanda tera. Kemudian disaring dan dianalisis menggunakan Atomic Absorption Spectrometry (AAS) (SNI, 2009).

Analisis logam $\mathrm{Cr}$ pada tanah sawah dan logam dilakukan secara spektofotometri serapan atom nyala. Ekstraksi sampel dilakukan dengan cara menimbang 1 gram sampel tanah/gabah yang telah dihaluskan ke dalam tabung digest dan memnambahkan $5 \mathrm{ml}$ asam nitrat dan $1 \mathrm{ml}$ asam perkolat kemudian didiamkan satu malam dan di panaskan sampai terbentuk endapan putih atau sisa larutan jernih sekitar $1 \mathrm{ml}$. Ekstrak didinginkan dan diencerkan dengan aquades menjadi $10 \mathrm{ml}$.

Hasil analisis laboratorium kemudian di korelasi untuk mengetahui hubungan antara jumlah logam $\mathrm{Cr}$ dalam air irigasi, tanah sawah dan gabah. Uji korelasi menggunakan SPSS 16.

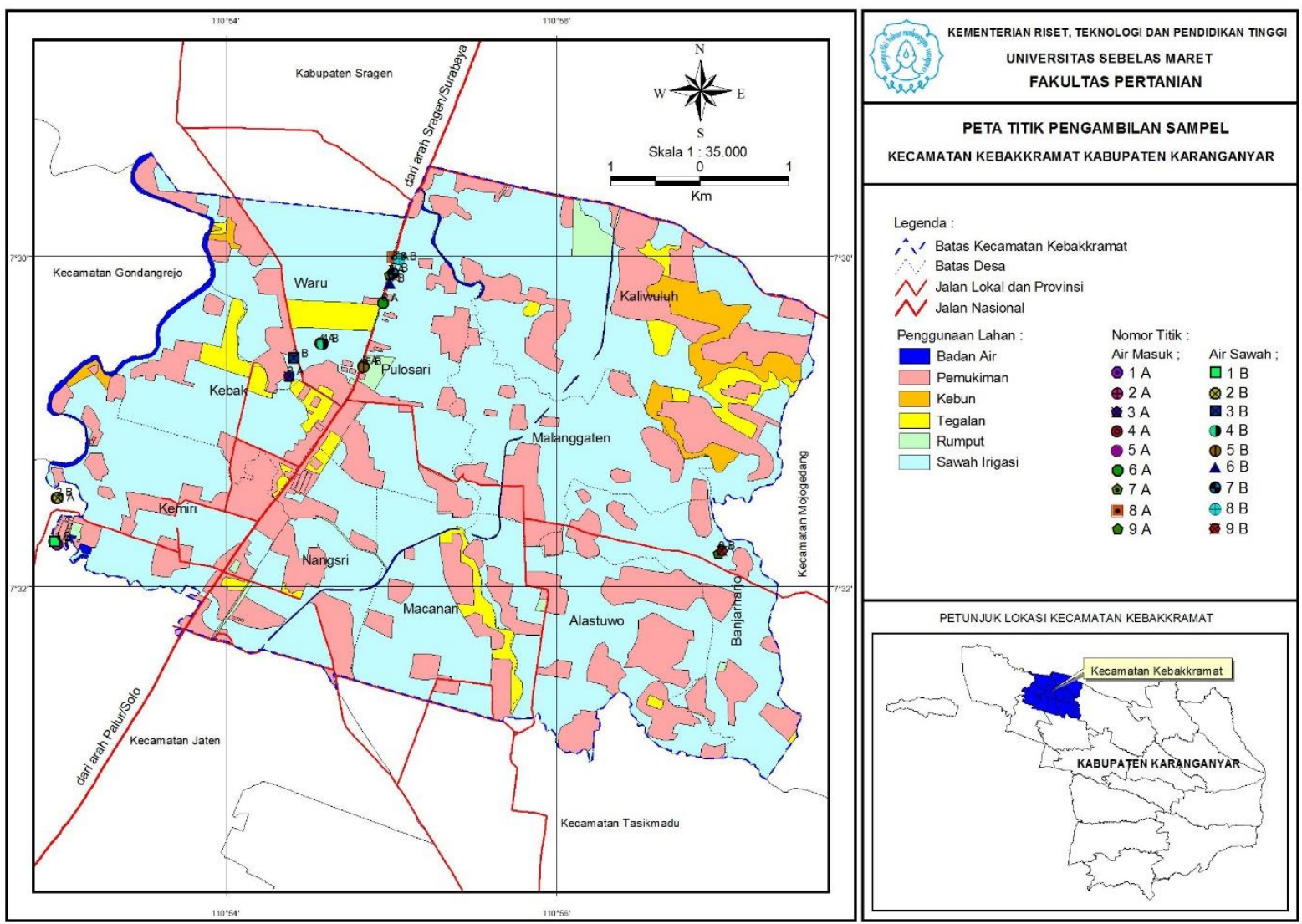

Gambar 1. Peta Titik Pengambilan Sampel 


\section{HASIL DAN PEMBAHASAN}

Tabel 1. Hasil Pengamatan Logam Cr

\begin{tabular}{ccccc}
\hline Titik & $\begin{array}{c}\text { Cr AM } \\
(\mathrm{ppm}) \times 10^{-1}\end{array}$ & $\begin{array}{c}\text { Cr AS } \\
(\mathrm{ppm}) \times 10^{-1}\end{array}$ & $\begin{array}{c}\text { Cr Tanah sawah } \\
(\mathrm{ppm})\end{array}$ & $\begin{array}{c}\text { Cr Gabah } \\
(\mathrm{ppm})\end{array}$ \\
\hline 1 & 0,30 & 0,75 & 2,10 & 0,30 \\
2 & 0,35 & 0,63 & 2,40 & 0,40 \\
3 & 0,12 & 0,15 & 2,30 & 0,20 \\
4 & 0,99 & 0,18 & 2,30 & 0,40 \\
5 & 0,26 & 0,50 & 1,20 & 0,30 \\
6 & 0,55 & 0,54 & 4,20 & 0,90 \\
7 & 0,51 & 0,20 & 3,90 & 1,80 \\
8 & 0,51 & 0,98 & 5,20 & 0,30 \\
Kontrol & 0,05 & 0,06 & 0,90 & 0,02 \\
\hline
\end{tabular}

Sumber: Analisis Laboratorium

Tabel 2. Korelasi antar Variabel Pengamatan

\begin{tabular}{lcccc}
\hline & Cr AM & Cr AS & Cr Tan & Cr Gab \\
\hline Cr AM & - & ns & ns & ns \\
Cr AS & ns & - & ns & ns \\
Cr Tan & ns & ns & - & ns \\
Cr Gab & ns & ns & ns & - \\
\hline
\end{tabular}

ket: ns. Tidak ada korelasi

Cr AM: Cr air masuk, Cr AS: $\mathrm{Cr}$ air sawah

Cr Tan: Cr tanah sawah, Cr Gab: Cr gabah

Tabel 2. menunjukkan bahwa logam $\mathrm{Cr}$ tidak saling berkorelasi, baik logam $\mathrm{Cr}$ dalam air masuk, logam $\mathrm{Cr}$ dalam air sawah, logam $\mathrm{Cr}$ dalam tanah sawah dan logam $\mathrm{Cr}$ dalam gabah. Hal ini menunjukkan tidak ada hubungan antara jumlah logam $\mathrm{Cr}$ dalam air masuk dan air sawah terhadap logam $\mathrm{Cr}$ dalam tanah dan gabah. Logam $\mathrm{Cr}$ dalam air masuk maupun air sawah rendah dikarenakan logam Cr tidak larut dalam air dan asam nitrat, tetapi larut dalam asam sulfat encer dan asam klorida (Vogel 1985) dalam Listiana (2013). Hal ini juga dijelaskan Listiana (2013) bahwa logam $\mathrm{Cr}$ dapat larut dalam kondisi air yang masam, sedangkan $\mathrm{pH}$ pada air masuk dan air sawah adalah netral sampai dengan agak alkalis.

Palar (1994) dalam Purniawati (2009) juga menjelaskan bahwa logam $\mathrm{Cr}$ akan melarut lebih tinggi pada kondisi $\mathrm{pH}$ rendah atau asam. Logam $\mathrm{Cr}$ yang tidak larut dalam air akan mengendap di dasar perairan atau mengalami sedimentasi, seperti yang dijelaskan Taftazani (2007) bahwa dalam perairan terjadi bermacam-macam proses kimia seperti pengompleksan dan sistem reaksi redoks yang dapat menyebabkan pengendapan dan atau sedimentasi logam $\mathrm{Cr}$ di dasar perairan, selain itu pada daerah sungai yang oksigen terlarut (DO) rendah, daya larut logam menjadi lebih rendah dan lebih mudah mengendap. Logam $\mathrm{Cr}$ dalam air irigasi yang rendah juga dapat disebabkan karena sudah adanya pengelolaan limbah dari industri sebelum di buang ke perairan.

Logam $\mathrm{Cr}$ dalam tanah sawah berdasarkan hasil penelitian lebih tinggi daripada logam $\mathrm{Cr}$ dalam air, hal ini disebabkan adanya akumulasi logam $\mathrm{Cr}$ dalam tanah sawah, seperti yang dijelaskan Budi (2004) dalam Purniawati (2009) bahwa kadar Cr yang rendah pada air sungai dapat terakumulasi pada lahan pertanian yang menggunakan air irigasi dari sungai tersebut, sehingga diperoleh kadar kromium yang tinggi pada tanah.

Logam Cr dalam tanah sawah tinggi, namun logam $\mathrm{Cr}$ dalam gabah rendah, hal ini dapat disebabkan karena sebagian logam $\mathrm{Cr}$ dalam tanah sawah berada dalam kondisi tidak tersedia sehingga serapan logam $\mathrm{Cr}$ oleh padi rendah seperti yang dijelaskan oleh Mengel dan Kirkby (1987) dalam Purniawati (2009) bahwa unsur Cr dalam tanah umumnya tidak tersedia bagi tanaman. Logam $\mathrm{Cr}$ yang tidak tersedia dalam tanah sawah dapat disebabkan karena logam $\mathrm{Cr}$ 
terjerap dalam koloid tanah, seperti yang dijelaskan Sutanto (2005) dalam Purniawati (2009) bahwa ion yang mempunyai potensial bersifat meracun yang ada dalam larutan tanah dan dapat dijerap oleh koloid lempung adalah $\mathrm{Pb}$, $\mathrm{Cd}, \mathrm{Hg}, \mathrm{Cr}$ dan $\mathrm{Sr}$.

Menurut Pilon dan Smits (2005) dalam Purniawati (2009) biovailabilitas (kemampuan dalam melarut) suatu polutan ditentukan oleh sifat kimianya, sifat-sifat tanah, kondisi lingkungan dan aktivitas biologis. Purniawati (2009) juga menjelaskan logam berat dapat mengalami berbagai macam reaksi jika masuk ke lahan sawah atau lingkungan. Reaksi-reaksi tersebut dipengaruhi oleh sifat-sifat tanahnya. Tanah Vertisol mempunyai kandungan lempung lebih tinggi dibandingkan pada tanah Entisol. Kandungan lempung yang tinggi akan menyebabkan luas permukaan jerapan yang semakin tinggi juga, dan ini membuat kelarutan logam $\mathrm{Cr}$ menurun.

\section{KESIMPULAN}

Kandungan logam $\mathrm{Cr}$ dalam air irigasi, air masuk, tanah sawah dan gabah tidak saling berkorelasi yang berarti tidak saling berhubungan. $\mathrm{Hal}$ ini dapat disebabkan karena jumlah logam $\mathrm{Cr}$ dalam air rendah karena tidak larut dalam air atau sudah melewati proses pengolahan oleh industri sebelum dibuang ke aliran air, sedangkan logam $\mathrm{Cr}$ dalam tanah sawah tinggi karena adanya pengendapan dari masukan sebelumnya.

\section{DAFTAR PUSTAKA}

Listina, V. 2013. Analisis Kadar Logam Berat Kromium (Cr) dengan Ekstraksi Pelarut Asam Sulfat $\left(\mathrm{H}_{2} \mathrm{SO}_{4}\right)$ menggunakan Atomic Absorption Spectrofotometry (AAS) di Sungai Donan (Cilacap) pada Jarak $2 \mathrm{~km}$ sesudah PT. Pertamina (Skripsi S1). Institut Agama Islam Negeri Semarang.

Purniawati, E. 2009. Serapan dan Ketahanan Azolla terhadap Logam Kromium pada Tanah Vertisol Jatikuwung dan Entisol Coomadu dengan berbagai Tinggi Genangan Air (Skripsi S1). Universitas Sebelas Maret. Surakarta.

SNI (Standar Nasional Indonesia). 2009. SNI 7387:2009. Batas Maksimum Cemaran Logam Berat dalam Pangan.
Suganda, H., Setyorini, D., Kusnadi, H., Saripin, I., \& Kurnia, U. 2002. Evaluasi Pencemaran Limbah Indstri Tekstil untuk Kelestarian Lahan Sawah. Prosiding Seminar Nasional Multifungsi dan Konversi Lahan Pertanian. Balai Penelitian Tanah. Bogor.

Suyana, J., \& Widijanto, H. 2002. Studi Kualitas Air dan Sumbangan Hara dari Irigasi Sidorejo Jawa Tengah pada Budidaya Padi Sawah. J. Sains Tanah. 1(2), 1-6. ISSN 1412-3606.

Taftazani, A. 2007. Distribusi Konsentrasi Logam Berat $\mathrm{Hg}$ dan $\mathrm{Cr}$ pada Sampel Lingkungan Perairan Surabaya. Prosiding PPI-PDIPTN 2007 Pustek Akselerator dan Proses Bahan BATAN Yogyakarta. Yogyakarta. 